\title{
Los homenajes de Ramón Gaya
}

\section{Ramon Gaya’s “Homages”}

\author{
José MuÑoz MiLlanes \\ City University of New York \\ munozmillanes@msn.com
}

Recibido: 23 de noviembre de 2010

Aceptado: 24 de noviembre de 2010

\section{Resumen}

Los homenajes de R. Gaya constituyen un ejemplo de crítica de un creador por otro, desde la preferencia y la admiración. En los homenajes Gaya cita obras ajenas (las modifica) para destacar en ellas su propio ideal de fluidez e inacabamiento. Y, por otra parte, al componer una atmósfera y sus objetos, conjura el mundo de sus autores.

Palabras clave: Interrupción, constelación, tránsito, cita, fluir, reproducción, obra inacabada, insistencia, repetición de la diferencia, donación de sentido.

\begin{abstract}
Ramón Gaya's "homages" constitute an example of an artist's criticism by another, from the point of view of preference and admiration. In his "homages" $\mathrm{R}$. Gaya quotes others' works (he modifies them) in order to emphasize in them his own artistic ideal: fluidity and open-endedness. On the other hand, by creating an atmosphere together with its objects, he conjures up their authors'world.
\end{abstract}

Keywords: Interruption, constellation, transit, quotes, streaming, reproduction, unfinished work, persistence, repetition of difference, sense donation. 
No es extraño que en algunos de los homenajes de Ramón Gaya el pintor haya sido sorprendido acechando: reflejado en la superficie del piano o en un rincón del espejo. Pues, como señala Miriam Moreno (2010, 144), los homenajes de Gaya son un buen ejemplo del "arte comprendido desde el artista", según lo entendía Nietzsche: en ellos "el pintor es a la vez el que contempla y el que pinta". En los homenajes Gaya nos abre la soledad de su estudio, pero no lo vemos pintar directamente, sino que asistimos a la profundización de su mirada en contacto con la del pintor elegido, tomado como ejemplo. Al observarlo críticamente, destacando ciertos rasgos superiores, se enriquece. En los homenajes Gaya, citando, cultiva esa atención extrema que, según su admirada Simone Weil (1994, 154), "constituye en el hombre la facultad creadora".

El tiempo de los homenajes es el de la pausa: el compás de espera en que se deja de pintar para recobrar fuerzas, para prepararse mejor a proseguir: "Le he dado, es verdad, toda mi vida a la pintura, aunque también haya necesitado pausas, descansos. Pero creo que eso - esas pausas, esos descansos- son pintar también. Abstenerse de pintar es pintar también. Y lo mío, en esos primeros momentos, no era propiamente abstenerme sino... serenarme, esperar que llegara el momento de trabajar" (Gaya, 2007, 274). Los homenajes de Gaya caen dentro de lo que Charles Sterling $(1981,27)$ llama "rhopographía", neologismo opuesto a "megalographía", la tradicional pintura narrativa (de mitos, episodios bíblicos o históricos) o "de tema", según Gaya. En la "megalographía" el cuadro es un momento pregnante, una instantánea donde los elementos significativos de una historia (sus protagonistas, lugares e instrumentos) se distinguen en una relación coherente: a esa relevancia obvia alude el griego "megalo" (grande). Pues la importancia de la pintura narrativa se debe a que el cuadro forma parte de un desarrollo implícito. Es un corte en una continuidad y, por tanto, su sentido se apoya en lo que supuestamente lo precede y lo sigue en la secuencia. El tiempo de los homenajes de Gaya, en cambio, es discontinuo: un hiato, una interrupción del acto de pintar. Y en esta suspensión los elementos del cuadro (vasos, cacharros, flores, frutas, tarjetas, fotos, sobre superficies improvisadas) son aparentemente insignificantes ("rhopos" en griego quiere decir "objetos triviales") porque carecen de identidad: cobran un valor estrictamente instantáneo que sólo se presta a ser consignado, descrito visualmente. Los elementos de los homenajes no aparecen integrados en una relación estable, sino desplazados a una constelación momentánea cuya tensión los altera revelando otro sentido 
mucho menos perceptible. En la misma entrevista Gaya insiste en que la calma de sus homenajes (la vida tranquila y callada de lo inanimado correspondiente a la expresión still life) no es más que ilusoria: "la mal llamada naturaleza muerta" (2007, 275). Pues en los homenajes todo está en tránsito, a punto de ser algo distinto. Gaya, enajenado por su aproximación al pintor que homenajea, no es más que un puro gesto: mirada que, al citarlo, a su vez lo varía, lo modifica. Mirada que al mismo tiempo obliga a Gaya a transformar de continuo el aspecto de su estudio para ponerse en sintonía, combinando objetos sacados de contexto y de función. Así es como en los homenajes repercute la tensión de la espera, subyacente a las pausas del pintar: en ellas el trabajo no deja paso al descanso total, sino a la admiración estimulante. Así la atención se afina y se prepara para después pintar mejor.

\section{III}

Al citar a otro pintor, los homenajes conjuran en el tiempo vacante del estudio el tiempo discontinuo de la aparición de la pintura: como es bien sabido, Gaya concibe la pintura como irrupción en el tiempo lineal; fluir instantáneo desde un fondo o reserva inagotable. En los homenajes, al citar a otro pintor, Gaya le da una "cita", lo llama (como se dice que los toreros citan al toro), lo invita a visitarlo en su estudio, lo invoca como en una sesión de espiritismo, a diferencia de Courbet, quien en su cuadro El estudio del artista (1855) congregó en persona "a todos aquellos que ayudan a mi causa y me apoyan en mi ideal y en mi actividad" (carta a Champfleury, 1854). En Gaya se trata de un intento de comunicar a solas y amistosamente, desde la admiración, con los grandes creadores del pasado, de consultarles: "A veces quería señalar que hay que acordarse de ellos, y no sólo hay que acordarse de ellos sino que hay que contar con ellos. No podemos dar un paso verdadero sin contar con todo eso" $(2007,239)$. Operación mágica que no tiene nada de absurda, ya que para Gaya la verdadera pintura es gracia ilimitada: no está fijada, siempre puede hacerse viva y carnalmente presente a contrapelo del tiempo histórico porque "no es el pasado, sino el presente, porque son cosas vivas" $(2007,239)$. Basta con propiciar este milagro con una actitud humilde: no interfiriendo, retirándose, cediendo, haciendo sitio para recibirla: "La gracia colma, pero no puede entrar más que allí donde hay un vacío para recibirla, y es ella quien hace ese vacío", escribe Simone Weil $(1994,61)$.

IV

Además de dejar en un segundo plano su propia obra, en los homenajes Gaya llena la espera preparándose para recibir la visita. Adapta el estudio para acoger al 
pintor admirado, dispone una atmósfera acorde y propicia alrededor de la cita: "siempre tenía una u otra reproducción sobre una mesa, entonces colocaba en torno unos objetos y creaba una atmósfera en torno a esa reproducción" $(2007,181)$. Su amiga Concha de Albornoz llamaba "altarcitos" a estas pequeñas instalaciones en honor y ofrenda al huésped admirado. (Antiguamente en los pueblos españoles las devotas podían adorar las imágenes religiosas sin tener que acudir a la iglesia, ya que recibían en casa la visita de unas capillitas portátiles a las que les improvisaban un altarcito de quita y pon en una cómoda o una camilla). De igual modo, gracias a los homenajes, el estudio libera a Gaya de la ordenación superficial de los museos: de la ordenación según criterios históricos (estilos, períodos o escuelas) que atenta contra la singularidad carnal y viva de la obra, ya que, según María Zambrano $(1989,11)$, "la pintura se instala en un tiempo diferente". Los homenajes, en cambio, le permiten elegir un modelo a instancias de la pura admiración, al margen del tiempo de su producción: "aunque seguían formándose esos 'altarcitos' de una manera natural, porque yo iba cambiando de reproducciones cuando me cansaba de verlas" $(2007,235)$. Como Gaya propugnaba para escándalo de los conservadores de los museos, en el estudio pueden alternarse homenajes a creaciones máximamente alejadas en el espacio y en el tiempo ("para mí tan vivo es un retrato de Velázquez como un cuadro con un almendro de Van Gogh, o como unas flores pintadas por un chino del siglo XI"; 2007, 87) o que invierten el orden cronológico: "Las Meninas no es un cuadro muy bueno para su época, para cuando fue pintado, no, el cuadro de Las Meninas está vivo, vivo en el presente ... es infinitamente más moderno que todo lo que acabo de ver en París" $(2007,107)$. Lo único que en ellos cuenta es la fuerza con que en la cita aún se advierte el estimulante pálpito vital de la pintura, la sensación de que "eso había que continuarlo, que seguirlo" $(2007,234)$.

En un escrito de 1971, "La función del estudio", Daniel Buren (The Studio Reader, 156) señala que el estudio es el borde alternativo a la rigidez del marco, el espacio de la producción que abre la obra de arte a la realidad de la que procede. En cambio, en los homenajes el estudio es el espacio de la exposición admirativa, donde Gaya aprecia, al margen de las teorías, "lo que es creación verdadera": si un cuadro "está vivo, si es verdadero, si es real" $(2007,87)$. Por otra parte, Gaya concibe el estudio como lo más opuesto, no sólo a un museo o a una sala de exposiciones, sino también a un taller de artista profesional. Para él el estudio no debe diferenciarse del espacio doméstico: "yo no tengo propiamente estudio, siempre he pintado en el salón o en la sala más luminosa de mi casa... Es verdad que aquí están los pinceles, pero esto es además el lugar donde vivimos, donde comemos, donde 
charlamos... Creo que se debe pintar en medio de la vida" (2007, 275 y 346-347). En los homenajes Gaya reajusta ligeramente su propio espacio vital para que los pintores invitados expongan allí en las mejores condiciones. Les "hace sitio" en él: les prepara un "altarcito" o rincón acogedor, como ha señalado Humberto Huergo.

Gaya siempre trató de evitar el borde cerrado, el encuadre: la figura definida que organiza el espacio en función del punto de vista, dando lugar a una imagen acabada (el cuadro, tan denostado por él, como "superficie animada", ventana: construcción de perspectiva). Los homenajes de Gaya no aparecen encerrados en un cuadrado o en un rectángulo, sino acogidos en un espacio simplemente acotado, en una concavidad propicia a la aparición o al despliegue de la pintura: un ángulo del estudio (en La poética del espacio Bachelard define el rincón como un repliegue del interior; 1964, 130). En los homenajes de Gaya el rincón es un espacio que se abre, pero no frontalmente: los ángulos rectos de las superficies se pintan aumentados o disminuidos para que los objetos aparezcan ladeados. Así el rincón se despliega esquivando la mirada, la cual no abarca la imagen, sino que parece caer sobre ella, sorprenderla en su fuga del cuadro por múltiples planos oblicuos y líneas diagonales, por cambios de escala, o bien fragmentada y desplazada. En los homenajes de Gaya la imagen desborda el cuadro porque a menudo el contorno de éste corta las figuras de los marcos o de los muebles del estudio, abriéndolas hacia fuera. Otras veces la imagen se sale del cuadro reflejada, total o parcialmente, en un espejo. O bien el borde desaparece hacia dentro cuando el estudio se convierte en un espacio de exposición de otros cuadros o espejos enmarcados, un tema presente en Gaya desde los interiores del castillo de Cardesse o las tiendas de antigüedades mexicanas.

\section{VII}

En los homenajes de Gaya el rincón del huésped no aparece físicamente delimitado. Lo define más bien una doble operación. Por una parte, el homenajeado no visita a Gaya con su creación original, sino en cita, modificado. Por otra, Gaya lo recibe con una composición o pequeña colección: agrupando objetos heterogéneos a su alrededor. Los homenajes de Gaya consisten en una reordenación o combinación de "objetos encontrados", de elementos previos desplazados: la cita de la obra ajena, desde el original; los objetos que la acompañan, desde el lugar de su uso (la huerta, el jardín, la cocina o la biblioteca): "Esos homenajes no están nunca compuestos de antemano. Se componen un poco solos, es decir, esas cosas que yo tengo 
en el estudio - cosas que me gustan o que tienen para mí resonancias- se organizan ellas solas... Se van ordenando solos los objetos" (2007, 270). El efecto del homenaje depende de su fundamental ambivalencia. Es improvisado: sus componentes vienen dados por la temporada o por la ocasión. Pero también implica un arte del aprovechamiento, de saber seleccionar y combinar lo que se tiene a mano, que Cernuda (1998, 426-427) elogia en el poema "Amigos: Enrique Asúnsolo": "ante alguna bebida / bien compuesta, ante algún plato / bien ordenado". Y en una prosa de 1932, "El espíritu lírico", Cernuda (1970, 75), como Gaya en sus homenajes, compone una atmósfera, sólo que para recibir a un poeta: "A imagen suya, actos, cosas y personas se agrupan en torno".

\section{VIII}

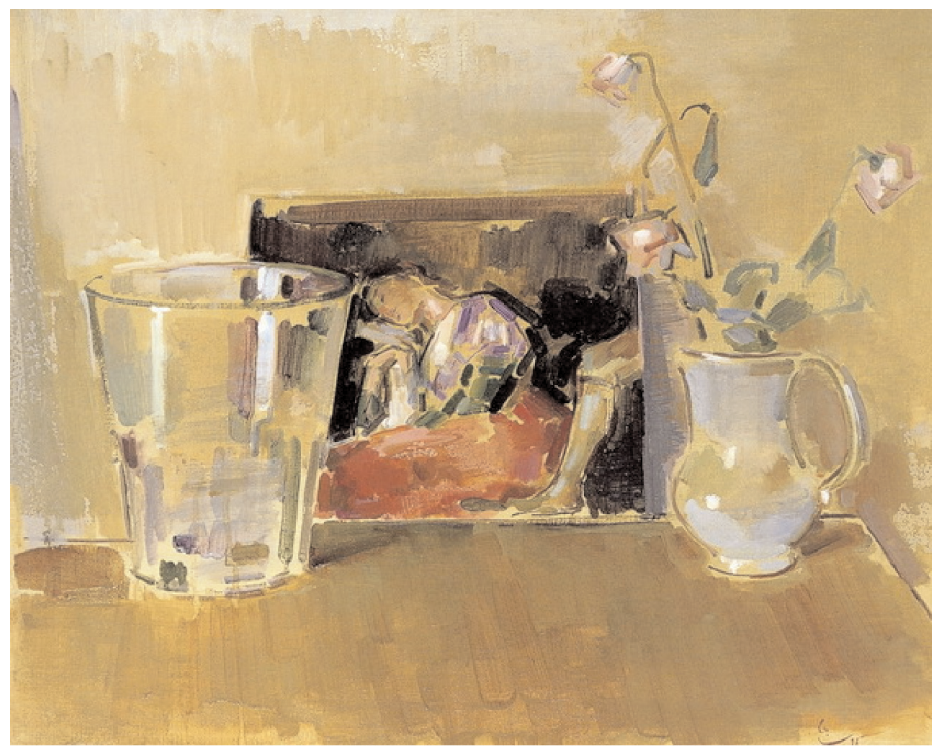

Pero en los homenajes se advierte sobre todo una disociación entre la cercanía física de sus elementos y la distancia de sus connotaciones o resonancias, entre el valor que las cosas adquieren en contacto con el grupo y el valor que evocan en razón de su procedencia. Como en los interiores decimonónicos (aunque sin su abigarramiento), Gaya selecciona y ordena los objetos con cierto criterio fetichista, por su dimensión imaginaria: se hace la ilusión de que, de algún modo, gracias a ellos, el estudio comunica con la función y el contexto desde los que han sido desplazados para recibir al huésped: "En el agua que ofrecemos sigue estando el manantial. Y en el manantial sigue estando la roca", afirma Heidegger $(1994,150)$ en su ensayo "La cosa". Pues, como observa Remo Bodei (2009, 47-48), a la manera de la 
obra de arte, aunque en menor medida, "las cosas desencadenan en quien las usa o las contempla una corriente de alusiones que brotan de ellas como de una única e inagotable fuente de donación de sentido".

\section{IX}

Por eso en los homenajes, tanto la cita del huésped como las cosas que la rodean, bajo su reposo aparente, padecen de inestabilidad. Tienen un aire inequívoco de estar de paso por el estudio. No aparecen asentadas o colocadas del todo, sino "movidas": posadas, apoyadas o entreabiertas en superficies improvisadas (el ángulo del piano, una mesa de borriquetas, repisas, estanterías, incluso las tablas del suelo) conforme a un orden no convencional. Esta conjunción provisional de volúmenes heterogéneos remite a las composiciones cubistas de los comienzos de la carrera de Gaya, a las que ha dedicado varios homenajes nostálgicos (en 1990, por ejemplo): "Sí, esas huellas del cubismo siguen siendo evidentes a lo largo de toda mi obra, incluso creo que un poco más marcadas en mi producción actual" (2007, 321). Para Gaya el cubismo supuso "una forma nueva de ver y concebir el cuadro, pero esa revolución se hacía aún dentro de la pintura, dentro de una substancia pictórica" $(2007,293)$. Gaya respeta el cubismo porque no abstrae de la realidad, sino que la reordena o recompone geométricamente sobre las superficies de un interior, al complicar y dinamizar el espacio en múltiples planos. Al igual que los homenajes, el cubismo altera y yuxtapone los objetos en un nuevo orden sin que dejen de ser del todo reconocibles, y sin que en ellos también deje de reconocerse su antiguo orden "natural". En mayor o menor medida la composición cubista subyace a los homenajes de Gaya, como se advierte en el caso extremo del bellísimo Homenaje a los pintores chinos (1946). En él las figuras (la cita de un pintor chino, la mesa, el espejo, el vaso de agua con una rosa blanca) casi han desaparecido en favor de la estilización geométrica de las superficies de apoyo (el passe-partout, el tablero de la mesa, la pared y el vidrio y el marco del espejo), fragmentadas y, al mismo tiempo, abruptamente comprimidas en la superficie del cuadro. (Otros rasgos cubistas de los homenajes de Gaya: el predominio, en general, de las cosas sobre las personas; la recurrencia de objetos de apariencia geométrica, como el metrónomo; la incorporación de cartas y tarjetas postales, de recortes de impresos). 
Los objetos que Gaya agrupa alrededor de la cita del artista homenajeado forman parte de su repertorio de la máxima belleza $(2010,384)$ : "unas flores, una copa de vidrio soplado, un vaso de agua". Parece como si la hospitalidad llevara a Gaya a compartir lo que, en su sencillez última, más lo afecta estéticamente. Pues en los homenajes las cosas, al ser miradas, ofrecen un valor añadido. Además de ser lo que se ve (una presencia no humana al alcance de la mano), estimulan la imaginación. Al mirar las cosas reposando en el estudio, sus cualidades secundarias o no substanciales (la textura, el brillo, la densidad, la transparencia, la lisura o rugosidad) apelan al tacto, al gusto o al olfato, sugiriendo una actividad humana, una pululación de gestos. Por eso Norman Bryson (1990, 70-75) ha podido hablar del funcionamiento háptico (es decir, por contacto parcial) de la mirada en las naturalezas muertas y en los interiores: los ojos ven las cosas, pero al mismo tiempo imaginan acariciarlas, olerlas, gustarlas, manipularlas. Al desplazarse las cosas al estudio, durante la colocación del homenaje o al quedar inmovilizadas, su valor de uso queda en suspenso. El contacto físico pasa a ser imaginado como una posibilidad de disfrute, igual que sucede con la preparación de ciertos placeres: cocinar, ordenar la biblioteca (según W. Benjamin y Borges), arreglar las flores o los preliminares de la ceremonia del té en la cultura japonesa.

\section{XI}

El carácter portátil de las cosas ayudó a que su valor de uso se estetizara, como reacción a la Revolución Industrial y al capitalismo. A este respecto se suele citar la carta (del 13 de noviembre de 1925) donde Rilke (1937, 374-375) se queja de la desaparición de las cosas "animadas, vividas, que nos tienen en cuenta" en favor de las cosas "vacías, indiferentes". Al ser desplazadas las cosas a los interiores, su valor de uso se idealiza y se propone como sustituto a otra dimensión suya igualmente imaginaria: el valor de cambio, que las convertía en mercancías. En aquel momento los poetas y artistas se afanaban en salvar a las cosas no sólo de su condición de mercancías, sino también de ser producidas industrialmente, en serie. Por eso Gaya en sus homenajes privilegia los objetos que, con su ligereza, mejor se prestan a evocar la productividad espontánea, impersonal, de la naturaleza: las flores, los frutos o las hierbas, que remiten a los árboles o a las plantas del huerto. (Para Gaya, 2010, 235-236, el huerto es una imagen poética, esencial, de la naturaleza, de la vida misma en su carnalidad). En su análisis de los interiores de Kierkegaard, Adorno $(1974,81)$ afirma que las flores, arrancadas, hacen posible que la vida orgánica acceda al espacio privado del hombre. En cierto modo, en sus homenajes, con 
la vegetación recolectada y expuesta, Gaya tiende a abrir su espacio vital a la naturaleza: a convertirlo en un jardín o en un huerto a escala reducida; en el manojo de perejil, en el racimo de uvas, en los tomates ("joyas de la naturaleza, más hermosos que una esmeralda") o en los ramos de flores: "Es que las flores a mí me gustan mucho ... En mi casa, en mi estudio, ha habido siempre muchas flores ... Que las flores estén bonitas en un cacharro, me interesa en mi casa" (2007, 168 y 236).

\section{XII}

La presencia de vegetales en los homenajes de Gaya es inseparable de la de los "cacharros" o recipientes: los soportes donde, recolectados, se exponen como en un centro de mesa: platos, vasos, jarras, tazas, copas, encima de manteles. Depositados los vegetales en tales recipientes, se acentúa su carácter doméstico (el valor "lárico" u hogareño reivindicado por Rilke), y el estudio adquiere cierto aire de comedor o de cocina, donde incluso se distinguen vasares y alacenas, y hasta utensilios netamente culinarios, como aceiteras y vinagreras. A la naturalidad de los vegetales acompaña la naturalidad adquirida de sus soportes: de los recipientes y hasta de los muebles y tapetes, "próximos al gusto popular, más que a la estética burguesa" (Andrés Trapiello, 2010). Se consigue así un "altarcito" o rincón muy humilde: sobre una mesa de pino lavado, cerámica tradicional, barro vidriado, cristal común, sin tallar. Se trata de una salvación estética de la modesta artesanía popular. Sus objetos son arrancados al uso común en el ámbito doméstico porque se los encuentra atractivos. Se aprecia en ellos un refinamiento discreto: son hermosamente sencillos por su funcionalidad y porque parecen naturales al haber sido producidos casi impersonalmente por un artista anónimo: "Es verdad que me interesa mucho más un objeto anónimo, sin valor artístico - un objeto común, un objeto de la vida, de la vida común, completamente- que un objeto destacado, un objeto de museo" (2007, 241). Y, a la hora de exponer en los homenajes, Gaya busca ante todo un recipiente "que sea popular, no porque yo sea especialmente populachero, sino porque ahí, en lo popular, no hay una personalidad interpuesta. Así que ponemos las flores en una jarra anónima, de uso, jarras murcianas o de Manises" (2007, 270). Este rescate burgués de la artesanía popular como reacción a la producción industrial arranca, como es sabido, del movimiento de Arts and Crafts e influyó en arquitectos como Adolf Loos o Frank Lloyd Wright, quienes, al ordenar sus interiores, renunciaban a la originalidad: tomaban prestada la elegancia anónima de la funcionalidad de los objetos tradicionales, en vez de innovar con sus propias creaciones. Como ha señalado Andrés Trapiello (2010), la combinación minimalista de "cacharros" u objetos populares para montar los homenajes la hereda Gaya de la Institución Libre de Enseñanza, tan ilusionada con el refinamiento de la pobreza "digna". Y en esta pre- 
ferencia estuvo acompañado por Zenobia Camprubí y los interiores que componía para sus tiendas de "Arte Popular Español": "nos hacen pasar a un aposento interior de la trastienda, tan sencilla y elegantemente dispuesto como todo lo que a ellos concierne. Nos sentamos en torno a una mesa de nogal sobre la que hay un finísimo florero verde con hojas de esparraguera haciendo juego con el bordado verde del tapete de Lagartera que cubre el centro del tablero" (Guerrero Ruiz, 1998, 375).

\section{XIII}

Afirma José Luis Pardo $(2006,63)$ que Gaya "es un excepcional pintor de recipientes -pocos han visto mejor que él un vaso vacío en toda su pureza". Pues en los homenajes de Gaya aparecen también vasos, tazas y copas sin nada dentro: "cacharros" que no exponen nada más que su propio vacío. Ni están llenos como cuando los usan en la cocina o en el comedor, ni tampoco como cuando en el rincón del estudio sirven para exponer flores, un ramillete de hierbas o un trozo de planta. Daniel Sabat (2005) ha llamado la atención sobre una entrada (del 13 de junio de 1957) del Diario de un pintor. Según Gaya, frente a los símbolos que surgen de suplantar la realidad imponiéndole un sentido, hay otros que están en la realidad misma. Símbolos donde el sentido no agota la concreción de la cosa, sino que brota de ella: la idealidad de lo simbolizado quedaría patente en la materialidad misma del objeto. Así las copas y los vasos en los homenajes: situados entre el resto de la colección que acompaña la cita del huésped, sólo a veces su falta de proporción, su escala diferente, delata que son símbolos, además de objetos. Por ejemplo, la concavidad vacía y abierta del recipiente simboliza ("expone") la hospitalidad del estudio: el ángulo o rincón que en él se despeja y ordena para acoger la pintura del creador admirado. Pero Daniel Sabat subraya el que también, con frecuencia, esos vasos y copas vacíos son del vidrio predilecto de Gaya, por su transparencia: el vidrio soplado o común. "El cristal tallado pierde, precisamente, lo que a mí me parece la máxima virtud del cristal puro y del vidrio soplado, la transparencia" $(2007,240)$. Este rasgo añadido de los recipientes vacíos, el ser de vidrio, simbolizaría (o llamaría la atención), por tanto, sobre una nueva característica del espacio del homenaje en el estudio: su transparencia, su condición de espacio interpuesto: "Muchas veces he puesto frutos o flores detrás de esos vasos. No ya unas flores dentro de un vaso sino detrás de un vaso. Y resulta que esas flores quedan... transformadas" (2007, 242). (Miriam Moreno, 2010, 142, ha señalado cómo este experimento de usar el vidrio de los vasos a manera de lente ha quedado registrado en un homenaje: "en 1951 Gaya pinta el detalle de la mano de Doña Mariana de Austria tras una copa... que es como una transparencia a modo de lente que acerca los trazos magistrales de Velázquez"). Al igual que una lente o un filtro, la transparencia, en cuanto mediación, condiciona: deja ver, pero de cierta manera. 
Para Gaya la imagen, al irrumpir inagotablemente en el tiempo histórico desde el fondo atemporal de la pintura, debe presentar cierto carácter fluido. No debe parecer estable, bien definida, sino depositada levemente, "a flor de lienzo" (Patrick Mauriès, 2006, 40): debe aparecer fresca como la dispersión de unas manchas húmedas en la pared o de un rubor en la piel. Para dar la impresión de que la imagen "mana" de un abismo acuático y está todavía formándose, Gaya la desencuadra, abriéndola hacia fuera. Pero, además, sus volúmenes no los define únicamente como son, con la ayuda de la línea y el color. Más bien los destaca: los da a ver mediante el brillo; gracias a las manchas de luz que caen sobre ellos, como incendiándolos (Svetlana Alpers, 1984, 244, recuerda que los antiguos tratadistas de pintura distinguían entre la luminosidad del objeto o lux y la luminosidad que lo resalta o lumen). Pues bien, en los homenajes de Gaya la transparencia tiene una función contrastante: paradójicamente consiste en cierto enrarecimiento del ambiente que, al atenuar levemente la luz del estudio, realza los destellos que de los objetos arranca otra luz venida desde fuera. O, como afirma Lévinas (2001, 60-61), "la atmósfera es la oscuridad misma de la imagen". Por eso Miriam Moreno $(2010,142)$ señala que en La mano de Doña Mariana de Austria el simbolismo del vidrio del vaso no es completo sin tener en cuenta, además, que el vaso está lleno de agua: que el espacio intermedio de la transparencia del vidrio está ocupado por otra sustancia incolora que, al enturbiarlo apenas, ilumina con un reflejo líquido, como una pequeña linterna en una habitación oscura, "los trazos magistrales" de la pintura-mancha de Velázquez. (Este destello acuoso también lo proyecta el agua de un vaso sobre el passe-partout en el Homenaje a los pintores chinos de 1946).

\section{XV}

En "The View from the Studio" (The Studio Reader, 130-133) Svetlana Alpers explica que en las pinturas de estudios la convención es que la luz que destaca los objetos, haciéndolos brillar, sea natural: llegue de un lado (del izquierdo la mayoría de las veces), supuestamente a través de una ventana invisible, pero que aparece, por ejemplo, en el Homenaje a Murillo (Santa María del Mar, 1974). En cambio, la penumbra diáfana del ambiente sería una luminosidad, también venida del exterior, pero indirecta, difusa, que se presta a ser tratada. A veces en los homenajes de Gaya esta penumbra interior es del todo artificial: la produce una lámpara o un quinqué con pantalla de cristal lechoso, uno de esos rasgos burgueses y galdosianos señalados por Trapiello (2010). En última instancia Gaya se propone reproducir 
dentro del estudio el efecto contrastante de los crepúsculos, o más concretamente, del atardecer, al que considera "la hora de la pintura", ya que en los crepúsculos la luminosidad ambiental también se atenúa, realzando las superficies incendiadas de lado por el sol.

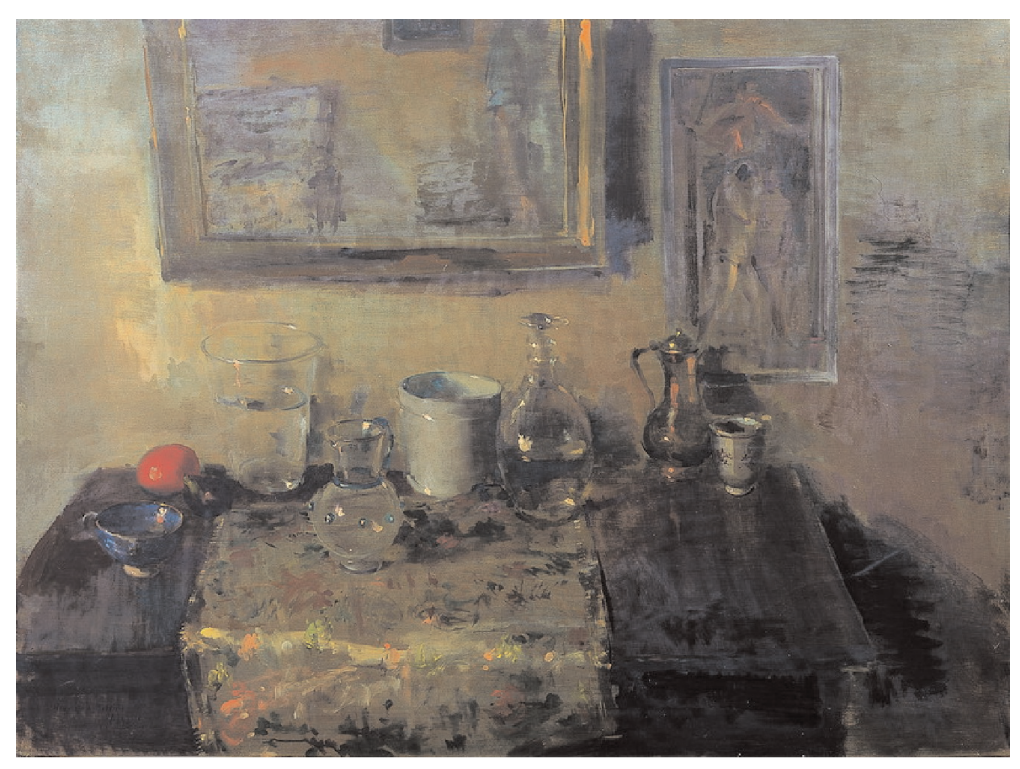

XVI

Además, en los homenajes Gaya capta esa densidad acuosa en la que destellan las cosas en la penumbra del interior, como en el Homenaje a Masaccio, de 1956. La atmósfera ensombrecida del estudio se impregna de colores en suspensión. Más bien matices de colores, tan poco naturales, tan sutiles, tan alejados de la percepción ordinaria a pesar de su aguda sensualidad, que (como los de los frescos pompeyanos) parecen casi irreales y sólo se pueden definir por aproximación: rojizos, morados, plateados, oliváceos, cobrizos, carnosos, mentolados, cremosos y, sobre todo, terrosos o polvorientos, igual que el aire de Murcia: "un leve espesor", "una sutil carnalidad", "una vigorosa sustancia desvaída" (Gaya, 2010, 237-238). Pero esta rara coloración no le es impuesta arbitrariamente al ambiente en penumbra. Al permearlo y predominar, es la base de la composición. El color ambiental liga, como el aliño de una ensalada, los objetos del homenaje: siendo heterogéneos, de procedencia diversa, los integra en el nuevo orden de la contigüidad. Se trata de ese fondo que, en la producción final de Gaya, será sustituido por un blanco que es vacío, no-color. Así, en los interiores mexicanos de los años 40 cierta carnalidad cremosa relaciona armónicamente el blanco de unas rosas con el azul de las figuras 
de un plato de cerámica china, o (en el Omaggio a Fattori, 1966) un azulado asocia el rojo de un tomate con el morado de los frutos y el negro de la planta del vaso. Mientras que el Homenaje al Tiziano de Nápoles, de 1994, está todo él entonado en morado: las uvas, el melocotón, la muceta del papa Pablo III. Gracias al color ambiental los elementos del homenaje hacen juego entre sí: se conjuntan o entonan y adquieren un carácter (denominado Stimmung en estética), lo mismo que la relación entre las notas de la escala de una tonalidad confiere un carácter determinado a la música. (Esta tonalidad musical de la coloración conjuntiva aproxima Gaya a Whistler, como ha señalado Humberto Huergo). Y, a su vez, este carácter o clima ambiental constituye la atmósfera evocativa del homenaje. La atmósfera que Gaya, al combinar los objetos, crea en torno a la cita para comunicar con la pintura de siempre $(2007,181)$. En última instancia la armonía de la composición del estudio aspira a compenetrarse con la armonía de la imagen invitada, sintonía que es casi identificación en el Homenaje a Vincent, de 1987, donde la separación entre los espacios de ambos pintores parece haberse abolido mágicamente. De ahí que, en los homenajes a artistas no plásticos, a músicos, por ejemplo, no importe no poder exhibir cita alguna de sus creaciones. La singularidad de la atmósfera que envuelve a los objetos basta para evocarlos, con la ayuda del título (Homenaje a Stravinsky, 1981).

\section{XVII}

Por sintonía, a Gaya el homenaje "se le tiñe del homenajeado" $(2007,43)$. Pero esta compenetración va más allá de la cesión del espacio y de la selección y colocación de la cita y los objetos. Además, hay que tener en cuenta el tratamiento de la imagen ajena elegida: "Lo que hago a partir de los cuadros de otros es... una visión, claro, personal, pero respetuosa, es decir, una visión equidistante entre la subjetividad y la objetividad" (2010, 537-538). En la relación de Gaya con la imagen ajena la subjetividad no supone distancia o libertad: el homenaje "no es ni por asomo una interpretación. Ni, como dije alguna vez, un comentario" (2010, 537). La subjetividad es más bien el citar, el "ponerse delante": el exponerse a ser impresionado por la imagen cercana. Ni la objetividad es tampoco, recíprocamente, resistencia de la imagen, sino apertura: una disposición de ésta a que la atención admirativa de Gaya descubra y exprese su fondo inagotable: "Cuando hago un homenaje, lo hago siempre desde mí" (2007, 43). Pues para Gaya la grandeza de la imagen verdadera consiste en que fluye sin parar: en que cada vez ofrece a la atención algún aspecto o detalle nuevo por donde se transparenta la profundidad insondable de lo real: "Van Gogh. La Guinguette es decididamente un milagro. La golondrina, que no había visto hasta hoy, es casi como un grito, no una golondrina, sino tan sólo su grito -solo- de golondrina. La individualidad de cada cosa, de cada banco del jardín, de 
cada mesa, de cada pareja, de cada enredadera" $(2010,449)$. El homenaje se propone dar fe de esta animación vital de la imagen verdadera, en cuanto despliegue inagotable de singularidades: "Los cuadros, hasta tal punto son seres vivos -los cuadros verdaderos, se entiende, porque un cuadro, digamos, de Ingres, como El baño turco, es siempre igual, muerto igual-, hasta tal punto son personas, que pueden cambiar muy bien de humor, de talante, de ánimo. Un buen día la Betsabé es un cuadro especialmente profundo, intenso; otro día, ese mismo cuadro amanece un tanto frío, inexpresivo; otro día se nos planta delante, sin más ni más, con descaro, como una flor ..." $(2010,447)$.

\section{XVIII}

Sin embargo, lo que inspira el homenaje (la singularidad plural de la imagen) no está disponible en el momento de su realización. Pues el homenaje se lleva a cabo en el estudio, en ausencia del original: "Porque al estar en México, no podía ver pintura, pintura que me interesara... Así que empecé a rodearme de libros y de reproducciones de los pintores que a mí me interesaban más... Yo me compraba todos los libros de arte habidos y por haber de todos los museos del mundo, tenía reproducciones de obras de Rembrandt, de Tiziano, de Tintoretto, de Rubens, de Velázquez... en la habitación" (2007, 234-235 y 178). En su exilio mexicano Gaya se benefició de lo que Walter Benjamin denomina "valor de exposición" de la imagen mecánicamente reproducida: su mayor poder de difusión. Pero, por otra parte, según Gaya, la imagen estampada es siempre una copia idéntica: una de las innumerables imágenes planas imprimibles técnicamente a partir de una matriz reductiva. Para él la reproducción gráfica traiciona la verdad de la imagen. Con su fijeza ("la tinta plana", "el odioso sombreado mecánico", 2010, 722) bloquea la transmisión del pálpito de la vida; el temblor que aflora en la fluidez, en la capacidad de renovación constante de la imagen, y que sí puede haber captado la mano del pintor: "En una reproducción, todo lo que en la obra original puede haber de naturaleza, no aparece registrado, se volatiliza" (2010, 221-222). De ahí que, según Gaya, los "creadores", como Giotto, pierdan en reproducción, mientras que los "artistas", como Piero della Francesca, o las obras endebles, ganen: el valor de la reproducción es inversamente proporcional al de la imagen original. La reproducción gráfica es una imagen reducida a superficie redundante: una imagen "copiada fielmente, pero no expresada, no comprendida" $(2007,363)$. Una imagen que no profundiza en la inagotable pululación de aspectos y detalles que es la verdad de la imagen original. 


\section{XIX}

Al pintar los homenajes en México, Gaya se sirvió de las reproducciones como una hypomnesis o aide-mémoire: una prótesis de memoria. Al no disponer de la singularidad del original, la reproducción le servía para recordar aspectos suyos que ella no había captado, pero que él había apreciado en su visión directa del cuadro: "la materia que falta en la reproducción la puedo suponer... porque conozco muchos Tiziano"; "para mí era un gusto vivir entre esas reproducciones que tenía en el estudio, acordarme de los cuadros que conocía" (2007, 179 y 239). (Y es de suponer que, a lo largo de su vida, al pintar los homenajes en su estudio, en mayor o menor medida Gaya combinó el recurso a las reproducciones con el recuerdo de sus visitas a los museos). Y, aunque se queje del "gusto actual por tantas lujosas ediciones de "museos imaginarios"' $(2010,222)$, Gaya a veces reconoce que la reproducción puede estimular no sólo la memoria del original, sino también suplirla: "Es que esa ausencia de la pintura que a mí me interesaba hizo que yo llenara mi estudio de reproducciones de cuadros, unos que había visto y otros que no había visto todavía" $(2007,238)$. Gaya parece, por tanto, admitir que la reproducción no siempre es una simple estampa plana y fija, pues circunstancialmente permite apreciar la riqueza de un original con el que aún no se ha tenido contacto directo. Este sería el caso de Cézanne, en la juventud murciana de Gaya, y de la pintura holandesa. Y, sobre todo, de la oriental, en la que, antes de volver a Europa, él pudo profundizar exclusivamente gracias a las reproducciones: "Aunque ya era una pasión mía antigua, también me tropecé en México con reproducciones de pintura china y japonesa antigua. Empecé a diferenciar unos de otros, cosa más difícil para nosotros, que con nuestra pintura occidental. Así que añadí reproducciones de Sesshu...Por lo tanto, entre los cuadros que pinté en México hay homenajes a los tres grandes pintores -Tiziano, Velázquez, Rembrandt- y a Sesshu" (2007, 236).

\section{$\mathrm{XX}$}

La experiencia del Museo Circulante de las Misiones Pedagógicas aclara cómo Gaya trata la imagen ajena en los homenajes. A consecuencia del encargo de Manuel Bartolomé Cossío, Gaya llegó a distinguir entre copias "de copista" y copias "de pintor". Los copistas profesionales, con su fidelidad mal entendida, con su imitación literal, demuestran no haber comprendido ni expresado el original. Sus copias equivalen a pastiches (como los de Manet) o, lo que es peor todavía, a reproducciones gráficas (Gaya y Cossío, 1991, 372, les achacan los mismos defectos que a éstas: el ser planas, "tapices aplastados", y fijas, de factura casi mecánica): "Los otros pintores que se habían presentado eran copistas de oficio, así que las copias 
que habían entregado eran como ésas que se ven en los museos, que son un remedo del cuadro, en el mejor de los casos, muy textual, pero sin entender el cuadro. Las nuestras eran copias de pintor, no eran unas copias hechas mecánicamente, y quizá por eso con una mayor comprensión de la obra copiada" $(2007,119)$. En los homenajes, al citar la imagen ajena, Gaya practica una fidelidad no redundante. Comprende y expresa la verdad de las imágenes admiradas: su fecunda inestabilidad. El margen de indeterminación que, abriéndolas, las potencia: las renueva, las vuelve fluidas, casi imperceptiblemente animadas, temblorosas. Gaya subraya que las imágenes de los grandes creadores están tan sólo abocetadas, en ciernes: "Con Miguel Ángel me sucede que encuentro más hechos, más logrados los Prigioni que hay en la Academia y que muchos consideran poco menos que bocetos inconclusos, que otras cosas suyas" $(2007,43)$. "Toda obra verdadera está siempre inacabada" $(2007,169)$ debido al "asco irreprimible que siente el creador adulto, real y verdadero, por la infantil obra de arte lograda, cristalizada" (2010, 110). La imagen en Velázquez, su modelo por excelencia, es "imprecisa, indecisa, insegura, movible, casi precaria" $(2010,118)$. Es una imagen, de puro exceso, lo menos definida posible: "Para Velázquez, la realidad viva no tiene límites, sino que es más bien imprecisa, movida, fluida, continuada; y a su pintura, claro, le sucede lo mismo. A Velázquez no le puede interesar una realidad compuesta, dispuesta de un cierto modo, plana, encajonada, inmóvil, fija. Los cuadros de Velázquez no es ya que estén abiertos de par en par, sino que carecen de cuadratura, que no son en absoluto cuadros... a todos estos seres, apareciendo precisamente en calma, los sabemos movibles, cambiantes, inseguros" (2010, 116-117).

\section{XXI}

Las imágenes verdaderas no llegan a cristalizar, a cerrarse en la fijeza, debido al funcionamiento discontinuo de la atención. La riqueza de la realidad mantiene al artista sensible en un estado de continua distracción: lo impulsa a ir de un detalle a otro, a abandonar un aspecto de lo que mira, reclamado por el nuevo con que lo sorprende. Las imágenes parecen abocetadas porque la atención del creador es fragmentaria, aísla: no puede integrar lo que mira en un todo porque, para apreciar cada detalle que se le ofrece, tiene que dejar momentáneamente en suspenso todo lo demás. Gaya concibe la atención del creador ideal como parcial. Para él, lo real no se abarca de un golpe la primera vez, sino que se capta poco a poco y sucesivamente, insistiendo ("yo no repito, insisto", 2010, 499): en cuanto novedad que destaca de lo ya conocido: "Lo completamente nuevo no sorprende tanto, porque uno ya lo esperaba así, como se presenta. Pero lo conocido ya y vuelto a ver pero distinto de la vez anterior es lo que verdaderamente sorprende, lo que sorprende por su nove- 
dad. Se podría decir que las variaciones sólo se encuentran en la repetición, no basta con el estreno. El estreno sólo sirve para que la segunda vez no lo sea”, escribe desde París a Juan Guerrero Ruiz el 19 de mayo de 1928 (2010, 324). Por eso, para Gaya, admirar una imagen consiste en una operación de ahondamiento casi arqueológica: en "arrancarle" o descubrirle nuevos aspectos y detalles a un todo siempre aplazado. De ahí también que Gaya, cuando admira una imagen, hable tanto de "trozos de pintura". La apreciación del todo pasa por el descubrimiento de ciertos detalles que impresionan; detalles que, con su extrema carnalidad, destacan del resto, apoderándose de la atención con una violencia casi física. Así, cuando, al regreso a Europa, Gaya se enfrenta a El nacimiento de la Virgen de Murillo en el Louvre: "Toda la figura era espléndida, pero, sobre todo, un brazo suyo, entre desmayado y vigoroso, de una tierna musicalidad muy robusta, hizo que me detuviera en seco... Aquel brazo no era tan sólo un bello y sublime trozo de pintura -aunque también lo era-, sino que, una vez alcanzada por él su misteriosa categoría de ser vivo... ese brazo era la... puerta viva por donde se penetraba en el gran lienzo de Murillo" (2010, 888-889). (Antes, "cuando acababa de cumplir diecisiete años y llegaba a Madrid, ya en mi primera visita al Prado me sorprenderían algunos fragmentos sumamente sustanciosos y, sobre todo, concentradísimos, de la por entonces muy desdeñada obra murillesca", 2010, 893). Y en el tazón de Los borrachos: "en ese tazón de vino -en su justeza, en su delgadez, en su quietud viva- se asoma, de pronto, don Diego entero y verdadero" $(2010,124)$. Ciertos detalles o "trozos de pintura" viva, animada, recurren en la obra de Gaya, tanto plástica como literaria: las manos de los retratos de Velázquez, la espalda de su Venus, la "sevillana durmiente" de El sueño del patricio de Murillo, el rostro de El niño de Vallecas, el brazo "caído, moribundo... lleno de significación... y sensual todavía" de La muerte de Lucrecia de Rosales (2010, 171). En "El inventor de La Gioconda" (2010, 217) él enumera otros: el vientre "modelado por una especie de temblor, de palpitación" de una Dánae de Tiziano, el "vivo turbante de un Rey David de Rembrandt" o "la temperatura justa de una mejilla pintada por Velázquez".

\section{XXII}

Gaya coincide con la concepción moderna del fragmento, tal como la expresa Friedrich Schlegel $(1978,79)$ : "Muchas obras de los antiguos han llegado a ser fragmentos. Muchas obras de los modernos lo son desde su génesis". El fragmento no es un residuo de la totalidad, sino que responde al detalle, una "apretada concentración" anterior a la cristalización de la imagen $(2010,498)$. El cuadro auténtico aparece ya de por sí "entrecortado" $(2010,171)$, desarticulado, sin terminar: una pululación de detalles o puntos de fuerza por donde todavía fluye, desplegándose, la rea- 
lidad originaria: "Cuando vuelvo a decir algo, en realidad lo digo por vez primera, lo vuelvo a pensar en su origen" $(2010,499)$. Gran parte de la obra de Gaya (toda la que es pintura de segundo grado: pintura inspirada por la pintura, cita de imágenes ajenas) está motivada por su atención a los detalles sobresalientes de los grandes creadores a los que admira. Hay en Gaya una fuerte pulsión de repetición de la diferencia, a insistir en la novedad del detalle: a "trabajar" o profundizar en la imagen dada. (En el Diario de un pintor y en las Anotaciones de diario inéditas queda constancia de cómo Gaya pinta muchos cuadros a partir de cuadros ajenos, llegando incluso a leerse que interviene o pinta en un cuadro de otro pintor). Se trataría de lo que se llama "abrir la imagen": pintar un nuevo cuadro fragmentario (e incluso toda una serie) donde el detalle o los detalles que le llamaron la atención en el original han desplazado a todo lo demás, se han independizado: de todo el ciclo de Santa Úrsula de Carpaccio en la Accademia veneciana Gaya se queda tan sólo con "los dos hombres asomados a la galería", por ejemplo $(2010,540)$. En el nuevo cuadro los detalles aparecen "desplegados": destacados, focalizados (aislados o amplificados) para aumentar la concentración de la mirada y que todavía se pueda apreciar mejor su inagotable fuerza vital, como explica Walter Benjamin (1980, 117): "La facultad de la fantasía consiste en el don de interpolar en lo infinitamente pequeño, de descubrirle a cada intensidad (en cuanto extensiva) su nueva plenitud comprimida; dicho en pocas palabras: en tratar cada imagen como si fuera la de un abanico cerrado que sólo al desplegarse cobra aliento". Así, después de admirar en el original la sutileza con que Sesshu había captado las cabezas de unos patos bajo el agua, Gaya siente el impulso de hacer justicia a este efecto, pintándolo a su vez: "Hay que estar ahí para percibir, para observar, para captar ese instante milagroso, y luego además, hay que volver a casa y pintarlo" $(2007,397)$.

\section{XXIII}

Pues la reiteración que resalta la novedad del detalle constituye un doble reconocimiento: del creador que ha sabido captarlo en el original y, a través de él, de la realidad que, con su inagotable fuerza vital, todavía aflora en el detalle, inspirando la repetición. Por eso habría que considerar homenajes, no sólo a los cuadros de Gaya así titulados, sino también a todos aquellos cuadros fragmentarios donde (aunque no aparezcan expuestos en el interior de su estudio) se evoca un cuadro ajeno a través de la fuerza gestual de un detalle desgajado: los "fragmentos de Velázquez" (la espalda tensa de una hilandera, la mirada atenta de una menina, un rostro asombrado en La fragua de Vulcano); o un desnudo reclinado del friso del Partenón; una Susana de Rembrandt, asustada de unos viejos invisibles; tres de las prostitutas de Solana haciendo la calle. Tanto en los homenajes implícitos como en los explícitos 
Gaya pone en práctica lo que Alfonso Pérez Sánchez $(1999,165)$ denomina una "fascinante taquigrafía": "mi pintura ha ido cambiando de aspecto, y antes yo pintaba con un gran acabado... mis cuadros de hoy... los encuentro más hechos, más llevados a cabo que aquéllos más acabados" $(2007,43)$. Al pintar el nuevo cuadro, fiel a su lema "Pintura... es quitar, desnudar" $(2010,637)$, Gaya no pretende recrear innecesariamente el original, sino resumirlo, despejarlo, aligerarlo: "Yo no tengo ninguna necesidad de pintar con el acabado de Murillo, porque gracias a que él ha existido yo puedo hacerlo con mucho menos, como un resumen, pero lo que yo quiero hacer es Murillo, es decir, lo mismo que Murillo; pero no el mismo cuadro ni la misma pintura" $(2007,39)$. La compenetración con el homenajeado se alcanza a través de lo que Gaya, a propósito de Velázquez, denomina "su huella": "la prueba, la huella que nos deja Velázquez para que nosotros sepamos que él ante la realidad ha visto eso" $(2007,76)$. Es decir, la compenetración se alcanza a través de la actitud del homenajeado como pintor, de su toma de posición ante la realidad: "lo que quiero es estar en el mismo sitio auténtico, real, vital, en el que está Murillo" $(2007,39)$. Al pintar el nuevo cuadro, Gaya pretende remontarse al embrión o boceto del original: asumir y exponer su inacabamiento latente. Dejar al descubierto, para que resalten, todos los aspectos fuera de lo común que impedían a la imagen original fijarse, cristalizar en cuadro.

\section{XXIV}

Estos aspectos no convencionales de los homenajes son los mismos que Gaya considera modélicos en la pintura de Velázquez. En primer lugar, la eliminación del borde, la ausencia de encuadre de la imagen fragmentaria, que hace que el detalle se abra y comunique con la realidad de la que procede. En los homenajes implícitos, tan numerosos en la última época de Gaya, el detalle queda suspendido en un blanco que no es color, que no es pintura ("ahora... mis cuadros están poco pintados e incluso dejo algunos trozos de la tela en blanco", 2007, 42-43): ese vacío sugerente que tan bien ha caracterizado Enrique García-Máiquez (2010, 257): "no pintar todo lo que hay... pero dejando que lo no pintado se transparente". De acuerdo con la economía, tan admirada por Gaya, de la pintura oriental, el vacío adquiere un valor positivo: es la fuerza de todo lo demás, de todo lo que ha quedado fuera del cuadro, pero que está haciendo surgir a la figura y la sostiene: "uno de los misterios de su pintura consiste en que no todo lo que se ve en ella ha sido pintado" (García-Máiquez, 2010, 257). En cambio, en los homenajes expuestos en el estudio, el detalle de la cita se abre a las cosas que lo rodean en un interior, que, por su falta de límites precisos, a su vez desborda el cuadro. Esa apertura permite a Gaya intensificar el valor expresivo del detalle, no sólo al aislarlo, sino también al amplificar- 
lo, rompiendo la escala de los objetos contiguos. Es lo que sucede en el magistral IX Homenaje a Velázquez, de 1948, donde la cara del niño de Vallecas (cuyo misterio lo fascinó a lo largo de su vida), "recortada" y dilatada, parece invadir la composición, empequeñeciendo el vaso de vidrio, con esa expresividad obsesiva, haunting, típica de los primeros planos cinematográficos.

\section{XXV}

La proximidad de los objetos al fragmento también favorece otro tratamiento típico del detalle en los homenajes: la atenuación del color que, con la ayuda del dibujo y la sombra, suele tradicionalmente definir los volúmenes. Con frecuencia el detalle aparece pintado con el mismo color "irreal", no natural, del ambiente del interior: así el cobrizo de la cabeza de la durmiente en el III Homenaje a Murillo, de 1949. Según Javier Barón $(2010,190)$, el empleo de la grisalla en el VII Homenaje a Velázquez. La Venus, de 1948, constituye el ejemplo extremo de tal acromatismo, aprendido precisamente del pintor sevillano, pues el detalle nuclear del cuerpo de la Venus "está representado en grisalla y el color se desplaza, con elegancia sutil y alusiva, a las dos florecillas a su pie, sobre un tapete cuyo rojo evoca, con marcada intensidad sensorial, la sensualidad que el pintor había velado en el cuerpo". Además, en los homenajes "independientes" (no expuestos en el estudio) de la última época Gaya deja zonas sin pintar aun dentro de las figuras mismas. Estos vacíos, cuando se trata de personas, refuerzan el tratamiento subversivo del cuerpo humano, una constante en los homenajes, pues en muchos de ellos Gaya lo fragmenta para realzar detalles chocantes de lo bajo, de las zonas que tradicionalmente se consideran de expresión más grosera y material: el vientre de Betsabé en un pastel de 1953 (Fragmento de Rembrandt. La Betsabé), el abdomen del pintor en el Homenaje a Tiziano de la primera época, de 1974. Sobre todo en su época final, Gaya no rehúye la cara, pero prescinde de su convencional espiritualidad y elevación, en favor de un sugestivo vacío: el rostro aparece inquietantemente reducido a un mero óvalo por unos rasgos que se esfuman, como sucede con la cara de La dama del abanico velazqueña en un óleo del 2002, o con la de la fotografía del homenaje al Galdós joven (2000). En el abocetamiento terminal de los homenajes el color también se amortigua debido al predominio del trazo, hacia el cual se retira. Gaya pinta directamente con el color, no lo incorpora: "Quizá por eso mi enamoramiento de la pintura china y japonesa... En ellas se ve cómo ya en los siglos XI, XII y XIII llegaron a una pureza tal que, con sólo un pincel y un poco de tinta china, hacían aparecer todo el color del mundo" (2007, 306-307). A la fijeza de la línea, asociada con la estabilidad de las formas, Gaya prefiere el dinamismo rítmico del trazo, su carácter instantáneo y nervioso de escritura. Como sucede con sus admirados pintores venecianos u orientales, en el inacabamiento de los trazos de 
Gaya, en su mancha o pincelada "acuarelada", el dibujo y la pintura terminan por confundirse. Por ello, el creador ejemplar puede ser evocado impersonalmente, como presencia de una ausencia, como huella: en el temblor de la imagen que se desvanece en el mismo momento de trazarse. Así los pintores chinos homenajeados en 1946 han desaparecido tras unas barcas y un monte apenas perceptibles y, en el homenaje de 1995, de Sesshu apenas queda rastro: unas simples manchas oscuras, austeras como sombras.

\section{Bibliografía citada}

(Los libros citados se identifican en el texto entre paréntesis, por la fecha de publicación y el número de página, que acompañan al nombre del autor).

Adorno, Theodor W., Kierkegaard. Konstruktion des Ästhetischen (Frankfurt am Main: Suhrkamp, 1974).

Alpers, Svetlana, The Art of Describing. Dutch Art in the Seventeenth Century (Chicago: The University of Chicago Press, 1984).

BACHelard, Gaston, La poétique de l'espace (Paris: Presses Universitaires de France, 1964).

BARÓN, Javier, "Velázquez, razón y cifra de la pintura de Ramón Gaya", Turia, no.95, junio-octubre, 2010.

Benjamin, Walter, Einbahnstrasse (Calle de dirección única), en Gesammelte

Schriften (IV-1) (Frankfurt am Main: Suhrkamp, 1980).

BodeI, Remo, La vita delle cose (Bari: Laterza, 2009).

Bryson, Norman, Looking at the Overlooked. Four Essays on Still Life Painting

(Cambridge, Massachusetts: Harvard University Press, 1990).

CERnudA, Luis, La realidad y el deseo (Madrid: Alianza Editorial / Biblioteca 30 Aniversario, 1998).

Cernuda, Luis, Crítica, ensayos y evocaciones (Barcelona: Seix-Barral, 1970). GarcíA-Máiquez, Enrique, "El hilo invisible", Turia, no.95, junio-octubre, 2010.

GAYA, Ramón, "Mi experiencia en las Misiones Pedagógicas. Con el Museo del Prado de viaje por España", conferencia pronunciada en la Residencia de Estudiantes en abril de 1991 y publicada en el 2007 en las páginas 372-377 del catálogo de la exposición madrileña sobre las Misiones Pedagógicas.

GaYA, Ramón, Ramón Gaya de viva voz. Entrevistas (1977-1998), selección y presentación de Nigel Dennis (Valencia: Pre-Textos, 2007).

GaYA, Ramón, Obra completa, edición al cuidado de Nigel Dennis e Isabel Verdejo (Valencia: Pre-Textos, 2010).

Guerrero Ruiz, Juan, Juan Ramón de viva voz, volumen I (1913-1931), (Valencia: Pre-Textos, 1998). 
HeIDegger, Martin, Conferencias y artículos, traducción de Eustaquio Barjau (Barcelona: Ediciones del Serbal, 1994).

LÉvinAs, Emmanuel, La realidad y su sombra, traducción de Antonio Domínguez Leiva (Madrid: Trotta, 2001).

MAURIĖs, Patrick, "Notas aleatorias sobre Ramón Gaya", en el catálogo Ramón Gaya. La hora de la pintura (Barcelona: Fundació Caixa Catalunya, 2006).

Moreno, Miriam, El arte como destino (Pintura y escritura en Ramón Gaya), (Granada: La Veleta, 2010).

PARDo, José Luis, "Ramón Gaya o el nacimiento de la pintura", en el catálogo Ramón Gaya. La hora de la pintura (Barcelona: Fundació Caixa Catalunya, 2006).

PÉREZ SÁnchez, Alfonso E., "El hoy de Ramón Gaya", en La obra pictórica de Ramón Gaya en Murcia (Murcia: Iberdrola, Ayuntamiento de Murcia y Museo Ramón Gaya, 1999).

RILKe, Rainer Maria, Briefe aus Muzot, 1921 bis 1926 (Leipzig: Insel Verlag, 1937).

SABAT, Daniel, "Vida y pintura en Ramón Gaya. El curso de una transparencia", 2005, en www.ub.edu / las_nubes / archivo / ocho /autores.

SCHLEGEL, Friedrich, Kritische und theoretische Schriften (Stuttgart: Reclam, 1978).

SterLING, Charles, Still Life Painting: from Antiquity to the Twentieth Century (New York: Harper and Row, 2a. ed., 1981).

The Studio Reader, edited by Mary Jane Jacob and Michelle Grabner (Chicago and London: The University of Chicago Press, 2010).

Trapiello, Andrés, "Con el permiso de Tolstói", conferencia pronunciada en las Jornadas conmemorativas del centenario de Ramón Gaya, Murcia, 2010.

WeIL, Simone, La gravedad y la gracia, traducción, introducción y notas de Carlos Ortega (Madrid: Trotta, 1994).

Zambrano, María, Algunos lugares de la pintura (Madrid: Espasa-Calpe, 1989). 